\title{
PREY FORAGING BEHAVIOR, SEASONALITY AND TIME-BUDGETS IN BLACK LION TAMARINS, Leontopithecus chrysopygus (MIKAN 1823) (MAMMALIA, CALLITRICHIDAE)
}

\author{
KEUROGHLIAN, A. ${ }^{1}$ and PASSOS, F. C. ${ }^{2}$ \\ ${ }^{1}$ Department of Wildlife Management, West Virginia University, Morgantown, West Virginia, 26505-6125, USA \\ ${ }^{2}$ Departamento de Zoologia, Universidade Estadual de Campinas, Campinas, Brazil \\ Correspondence to: Fernando de Camargo Passos, Departamento de Zoologia, Universidade Federal do Paraná, \\ C.P. 19020, CEP 81531-990, Curitiba, PR, Brazil, e-mail: fpassos@bio.ufpr.br \\ Received May 13, 1999 - Accepted July 18, 2000 - Distributed August 31, 2001
}

\begin{abstract}
Foraging behavior, seasonality and time-budgets in the Black Lion Tamarin (L. chrysopygus) was observed in the Caetetus Ecological Station, South-eastern Brazil, during 83 days between November 1988 to October 1990. For the full dry season we found that animal prey represented $11.2 \%$ of the black lion tamarin diet, while during the wet season they represented $1.9 \%$. Foraging behavior made up $19.8 \%$ of their total activity in the dry season and only $12.8 \%$ in the wet season. These results point out that animal prey are relatively more important during the dry season, due to reduced availability of other resources, e.g. fruits, and that a greater foraging effort is required when a larger proportion of the diet is animal prey.
\end{abstract}

Key words: Leontopithecus chrysopygus, foraging behavior, seasonality, time-budgets, Callitrichidae.

\section{RESUMO}

\section{Comportamento de forrageio por presas, sazonalidade e orçamento temporário das atividades do mico-leão-preto, Leontopithecus chrysopygus (Mikan 1823) (Mammalia, Callitrichidae)}

O comportamento de forrageio por presas, a sazonalidade e o orçamento temporal das atividades no mico-leão-preto (L. chrysopygus) foram observados na Estação Ecológica dos Caetetus, sudeste do Brasil, durante 83 dias, entre novembro de 1988 e outubro de 1990. Para toda a estação seca, observouse que as presas animais representaram $11,2 \%$ da dieta do mico-leão-preto, enquanto na estação chuvosa elas foram responsáveis apenas por $1,9 \%$. O comportamento de forrageio por presas compreendeu $19,8 \%$ de sua atividade total na estação seca e $12,8 \%$ na estação chuvosa. Esses resultados indicam que as presas animais são relativamente mais importantes durante a estação seca, devido à redução na disponibilidade de outros recursos, como frutos, e que o maior esforço de forrageio é exigido quando a maior proporção da dieta é composta por presa animal.

Palavras-chave: Leontopithecus chrysopygus, comportamento de forrageio, sazonalidade, orçamento temporário, Callitrichidae.

\section{INTRODUCTION}

The black lion tamarin, Leontopithecus chrysopygus Mikan 1823, is one of the endemic and highly endangered primate species from the Atlantic Forest of South-eastern Brazil (CoimbraFilho, 1976). It is the only lion tamarin (genus Leontopithecus) which does not inhabit a restricted 
region of coastal rainforest (Rylands, 1993). Its range extends inland as far as $500 \mathrm{~km}$, on the drier, more seasonal tablelands (the Planalto) of São Paulo State. This region has a distinct dry season, and the original vegetation cover, of which less than $10 \%$ remains (Victor, 1975), consists primarily of broad-leaved semideciduous tropical forest (Torres de Assumpção, 1983).

Lion tamarins are considered primarily insectivores and frugivores (Coimbra-Filho \& Mittermeier, 1977; Rylands, 1993; Passos, 1999), and in the wild they consume mostly fruits, exudates, animal prey and nectar. Animal prey make up a relatively small proportion of the diet and are costly to obtain, but its nutritional value make it an essential component of their diet (Peres, 1986). In this note, we present our observations on prey foraging. We then compare them with studies of other lion tamarin species and discuss some of the unique aspects of black lion tamarin foraging in relation to the seasonal variability within their endemic range and their time-budgets.

\section{MATERIAL AND METHODS}

We studied the foraging behavior of a group of black lion tamarins at the 2,179 ha Caetetus Ecological Station in South-central São Paulo State, Brazil. Caetetus Ecological Station is an isolated patch of semideciduous mesophytic forest. The climate of the region has a well-defined seasonality with the dry season from April to September (35$75 \mathrm{~mm}$ ), a wet season from October to March (120$200 \mathrm{~mm}$ ) and annual rainfall averages between 1,000-1,600 mm.

We observed the group from November 1988 to June 1989 and April to October 1990, following the same group for 83 days. The studies included observations from both the wet and dry seasons. The group ranged from 7 to 5 individuals and their activities were recorded by daily scan sampling at 15 minute intervals. The group was followed using radiotelemetry and five categories of behavior were quantified through scan sampling: traveling, resting, foraging for animal prey, feeding and "others".

\section{RESULTS AND DISCUSSION}

The behavior used by L. chrysopygus to locate and capture animal prey was manipulative, specific-site foraging as described by Rylands
(1993). The black lion tamarins used a wide variety of microhabitats (Passos \& Keuroghlian, 1999), searched in among dry palm leaves, twigs, under loose bark, in tree cavities of all sizes, and in moss patches and epiphytes. More than half of foraging records are in the middle layers of the forest between 8 to 15 meters (Passos, 1994).

An analysis of the diurnal time budget of a group of black lion tamarins, showed that $68 \%$ of the foraging occurred in the afternoon. More prey were captured during the afternoon as well $(n=$ 21 total prey items), suggesting that the increase in foraging effort was associated with searching and capturing animals.

The tamarins at the Caetetus Ecological Station showed an increase in animal prey consumption during the transitional months from the end of the dry season to the beginning of the wet season, $1.6 \%$ to $5.0 \%$, respectively. The beginning of the wet season is a period when the abundance and activity of certain insects increases, e.g. tettigoniids, numerous homopterans, isopterans (termites) and formicids (ants) (Wolda, 1978; pers. obs.). Intensified prey foraging and/or increased capture success by the tamarins may accompany this period and explain the observed pattern. In addition, frogs became very active after the rains began. They were absent from the diet of the tamarins toward the end of the dry season, but composed $0.6 \%$ during the first month of the wet season.

For the full dry season (April to September) at the Caetetus Ecological Station, we found that animal prey represented $11.2 \%$ of the black lion tamarin diet, while during the wet season (October to March) they represented $1.9 \%$ of the diet. In addition, foraging behavior made up $19.8 \%$ of their total activity in the dry season and only $12.8 \%$ in the wet season. These results point out: 1 . that animal prey are relatively more important during the dry season, due to reduced availability of other resources, e.g. fruits, and 2. that a greater foraging effort is required when a larger proportion of the diet is animal prey.

Seasonal differences in the use of animal prey were not apparent for other lion tamarin species (Peres, 1986; Rylands, 1989). Temporal differences have been found for the black lion tamarins, but studies have produced conflicting results (Keuroghlian, 1990; Passos, 1992; Valladares-Padua, 1993). Two of the black lion tamarin groups studied by Valladares-Padua (1993) at the Morro do Diabo 
State Park showed a wet season increase in animal prey foraging, while the other two groups did not show seasonal differences, i.e. monthly variability was just as pronounced as seasonal changes. He attributed the wet season increases to declines in fruit resources and peaks of insect abundance.

Physiognomic, areal and local weather differences between the two reserves, which affect seasonal prey abundance, may explain the conflicting results above. The Caetetus Ecological Station is situated above $500 \mathrm{~m}$ of altitude on the edge of a plateau, while the much larger (15 times) Morro do Diabo State Park is on the flood plain of a large river, the Paranapanema, below $350 \mathrm{~m}$ of altitude. Dry season rainstorms, which have a strong effect on insect cycles (Wolda, 1978), are often patchy events on the Planalto, reaching some regions, but not others. Despite forest similarities, we expect that animal prey trends are highly variable within and between seasons, and may frequently be different for these two reserves.

However, the study of Valladares-Padua (1993) and our data indicated that the prey foraging of at least L. chrysopygus was quite variable. Black lion tamarins used a wide variety of microhabitats (Passos \& Keuroghlian, 1999) and forest types (Valladares-Padua, 1993), and their foraging habits appeared to be adjusted to the daily, monthly, and seasonal cycles of prey availability (this study), different of the other lion tamarin species (Peres, 1986; Rylands, 1989).

From $19 \%$ to $31 \%$ of the animal prey foraging by L. rosalia (Peres, 1986) and nearly
$50 \%$ by L. chrysomelas (Rylands, 1989) occurred on bromeliads. This suggests that these tamarins have relatively specialized prey foraging behavior. Although comparable data were not collected for L. chrysopygus, their prey foraging effort appeared to be distributed more evenly among the available microhabitats. The forests in their range do not have a single, abundant microhabitat where animal prey are located consistently, and as a consequence, the black lion tamarins may need to search regularly in a variety of locations.

If searching several types of microhabitats for animal prey in a mixture of forest types requires greater effort, then, as observed by Passos \& Keuroghlian (1999), black lion tamarins should spend less time resting than other lion tamarins (Table 1, see inactivity). Similarly, in a comparison of two callitrichid species, Terborgh (1983) reported that the emperor tamarin (Saguinus imperator) spent more time foraging for insects and as a result rested less than the saddleback tamarin (Saguinus fuscicollis). Valladares-Padua (1993) reported inactivity as the dominant component of the black lion tamarin time budget (Table 1), and the levels reported by Valladares-Padua were much higher than those for other lion tamarins. We believe that the divergent results of our studies were due to methodological differences in defining and identifying inactivity, or can represent that the activity patterns at least in L. chrysopygus was quite variable (see Table 1).

The regular use of a variety of spatially dispersed foraging sites (Passos \& Keuroghlian, 1999) should also be associated with relatively large area requirements.

TABLE 1

Activity-inactivity budgets of lion tamarins (Leontopithecus spp.). Percent values are shown for observations of total activity, inactivity and animal prey foraging (a subdivision of total activity).*

\begin{tabular}{|c|c|c|c|c|c|}
\hline \multirow{2}{*}{ Species } & \multicolumn{3}{|c|}{ Activity category } & \multirow{2}{*}{$\begin{array}{l}\text { N. of } \\
\text { groups }\end{array}$} & \multirow{2}{*}{ Source } \\
\hline & Total activity & Inactivity & Foraging & & \\
\hline L. chrysopygus & $83.0-86.2$ & $13.8-17.0$ & $13.2-18.3$ & 1 & This study \\
\hline L. chrysopygus & $30.0-47.0$ & $53.0-70.0$ & 3.0 & 4 & Valladares-Padua (1993) \\
\hline L. rosalia & 73.3 & 26.7 & 12.4 & 1 & Peres (1986) \\
\hline L. chrysomelas & 80.0 & 20.0 & 13.0 & 1 & Rylands (1989) \\
\hline
\end{tabular}

* To allow comparison, we have presented inactivity as the sum of resting and social activities for Peres (1986) and Rylands (1989). This was not possible for the data presented by Valladares-Padua (1993), so the inactivity shown for his study do not include social activities. 
For example, folivorous-frugivorous howler monkeys, e.g. Alouatta palliata (Milton, 1980), which forage among a limited number of sites have home ranges of approximately 30 ha, while omnivorous, wide-ranging capuchin monkeys, e.g. $\mathrm{Ce}$ bus albifrons (Terborgh, 1983), have home ranges of 150 ha or more. As shown in Table 2, black lion tamarins have larger home ranges than other lion tamarins, but mean daily ranges are similar.

These observations of L. chrysopygus point out: 1 . the relatively even use of a variety of microhabitats for foraging; 2 . temporal adjustments of foraging behavior and diet to available resources; 3. minimal rest; and 4. large area requirements, when considered in combination and compared with other lion tamarins, describe a species adapted to seasonal environment. Survival in this environment will be closely linked to the efficient use of temporally and spatially clumped resources of varying quality, principally fruits and animal prey. The home range size will also be influenced by other biological characteristics such as biomass, group size and density, and other factors.

The larger body size of the black lion tamarin in comparison to the other lion tamarins (Lorini \& Persson, 1990), may be a factor related to the use of a larger home range. However, the seasonality of the region and their foraging behavior appear to be other factors influencing their ranging behavior.

TABLE 2

Mean daily range (m) and home range (ha) estimates for the lion tamarins (Leontopithecus spp.).

\begin{tabular}{|l|c|c|c|l|}
\hline \multicolumn{1}{|c|}{ Species } & Mean daily range (m) & Home range (ha) & $\begin{array}{c}\text { N. of } \\
\text { groups }\end{array}$ & \multicolumn{1}{|c|}{ Source } \\
\hline L. chrysopygus & $1,977-2,289$ & $>118$ & 1 & This study \\
\hline L. chrysopygus & & $66-133$ & 2 & Carvalho \& Carvalho (1989) \\
\hline L. chrysopygus & $1,362-2,088$ & $113-199$ & 4 & Valladeres-Padua (1993) \\
\hline L. rosalia & $1,339-1,533$ & $36-67$ & 7 & Dietz et al. $(1997)$ \\
\hline L. chrysomelas & & $66-86$ & 4 & Dietz et al. $(1994)$ \\
\hline L. chrysomelas & $1,552-1,954$ & 36 & 1 & Rylands (1989, 1993) \\
\hline
\end{tabular}

The unique aspects of their prey foraging behavior will be important to consider for the conservation of black lion tamarins (Rylands, 1993). Future investigations should attempt to identify the use and value of particular microhabitats, or more likely a diversity of microhabitats, to successful prey foraging and the fulfillment of nutritional requirements. The availability of prey monthly and seasonally and in different regions should also be quantified to determine their importance in local behavioral patterns (Rylands, 1993).

The observations which show that the foraging behavior of L. chrysopygus is more flexible than that of its congeners (Passos \& Keuroghlian, 1999; Valladares-Padua, 1993; this study) may at first appear to simplify management strategies. However, the broad-leaved semideciduous forests of its range have been disproportionately destroyed in South-eastern Brazil leaving most of the surviving populations in highly disturbed habitat remnants (Coimbra-Filho, 1976; Valladares-Padua, 1993). In addition, the black lion tamarins have relatively large area requirements, and, as indicated above, the carrying capacity of their environment may be relatively low in certain regions and at certain times of the year. Therefore, conservation units must not only incorporate sufficient area for the ranging habits of the tamarins, but for the maintenance of habitat diversity as well.

Acknowledgments - We are grateful to the administrators and staff of the Caetetus Ecological Station and the Forestry Institute (IF) of São Paulo, Dr. Cory Teixeira de Carvalho for his continuous support, José Carvalho for his field assistance, Édson P. Teixeira (IF) for identification of the insect fragments, Dr. Faiçal Simon (chairperson of the black lion tamarin committee during the study), Don Eaton for editing comments, and CAPES and Fundação MB. Contribution number 1220 from Departamento de Zoologia, Universidade Federal do Paraná. 


\section{REFERENCES}

CARVALHO, C. T. \& CARVALHO, C. F., 1989, A Organização Social dos Savins-pretos, Leontopithecus chrysopygus (Mikan, 1823), Na reserva em Teodoro Sampaio, São Paulo (Primates, Callitrichidae). Revta. Bras. Zool., 6(4): 707-717.

COIMBRA-FILHO, A. F., 1976, Leontopithecus rosalia chrysopygus (Mikan, 1823) o mico-leão-preto do Estado de São Paulo (Callithricidae, primates). Silvicultura, São Paulo, 10: 1-36.

COIMBRA-FILHO, A. F. \& MITTERMEIER, R., 1977, Conservation of the brazilian lion tamarins Leontopithecus rosalia, pp. 59-94. In: P. Rainier \& G. H. Bourne (eds.), Primate Conservation. Academic Press, New York.

DIETZ, J. M., PERES, C. A. \& PINDER, L., 1997, Foraging ecology and use of space in wild golden lion tamarins (Leontopithecus rosalia). Amer. J. Primatol., 41: 289-305.

DIETZ, J. M., SOUZA, S. N. F. \& SILVA, J. R. O., 1994, Population structure and territory size in golden-headed lion tamarins, Leontopithecus chrysomelas. Neotropical Primates, 2(suppl.): 21-23.

KEUROGHLIAN, A., 1990, Observations on the behavioral ecology of the black lion tamarin (Leontopithecus chrysopygus) at Caetetus Reserve, São Paulo, Brazil. M. S. Thesis, University of West Virginia, Morgantown.

LORINI, M. L. \& PERSSON, V. G., 1990, Nova espécie de Leontopithecus Lesson, 1840, do sul do Brasil (Primates, Callitrichidae). Bol. Mus. Nac., N. S., Zool., Rio de Janeiro, 338: 1-14.

MILTON, K., 1980, The foraging strategy of howler monkeys. Columbia University Press, New York.

PASSOS, F. C., 1992, Hábito alimentar do mico-leão-preto, Leontopithecus chrysopygus (Mikan 1823) (Callitrichidae, primates), na estação ecológica dos caetetus, Município de Gália, SP. M. S. Thesis, Universidade Estadual de Campinas, Campinas.

PASSOS, F. C., 1994, Behavior of the black lion tamarin, Leontopithecus chrysopygus, in different forest levels in the Caetetus Ecological Station, São Paulo, Brazil. Neotropical Primates, 2(suppl.): 40-41.
PASSOS, F. C., 1999, Dieta de um grupo de mico-leão-preto, Leontopithecus chrysopygus (Mikan) (Mammalia, Callitrichidae), na Estação Ecológica dos Caetetus, São Paulo. Revta. Bras. Zool., 16(suppl. 1): 269-278.

PASSOS, F. C. \& KEUROGHLIAN, A., 1999, Foraging behavior and microhabitats used by black lion tamarins, Leontopithecus chrysopygus (Mikan) (Primates, Callitrichidae). Revta. Bras. Zool., 16(suppl. 2): 219-222.

PERES, C. A., 1986, Costs and benefits of territorial defense in golden lion tamarins, Leontopithecus rosalia. M. S. Thesis, University of Florida, Florida.

RYLANDS, A. B., 1989, Sympatric Brazilian callitrichids: the black tufted-ear marmoset, Callithrix kuhli, and the golden-headed lion tamarin, Leontopithecus chrysomelas. J. Human Evol., 18: 679-695.

RYLANDS, A. B., 1993, The ecology of the lion tamarins, Leontopithecus: some intrageneric differences and comparisons with other callitrichids, pp. 296-313. In: A. B. Rylands (ed.), Marmosests and tamarins: systematics, behaviour and ecology. Oxford University Press, Oxford.

TERBORGH, J., 1983, Five new world primates: a study in comparactive ecology. Princeton University Press, Princeton.

TORRES DE ASSUMPÇÃO, C., 1983, Conservation of primates in Brazil: Atlantic forest primates, pp. 34-48. In: D. Harper (ed.), Proceedings of the symposium on the conservation of primates and their habitats. Vol. 1. Primate conservation in the wild. University of Leicester, Leicester.

VALLADARES-PADUA, C., 1993, The ecology, behavior and conservation of the black lion tamarins (Leontopithecus chrysopygus, Mikan 1823). Ph.D. Dissertation, University of Florida, Gainesville.

VICTOR, M. A. M., 1975, A devastação florestal. Sociedade de Silvicultura de São Paulo, Unipress, São Paulo.

WOLDA, H., 1978, Seasonal fluctuations in rainfall, food and abundance of tropical insects. J. of Anim. Ecol., 47: 369-381. 